\title{
ANALISIS MINAT BELAJAR SISWA TERHADAP MATA PELAJARAN FISIKA DI SMA NEGERI 1 SAKTI
}

\author{
Hamdi $^{1}$,Cut Kurniyawati Rahim ${ }^{2}$ \\ ${ }^{1,2}$ Program Studi Pendidikan Fisika Universitas Jabal Ghafur Sigli \\ cutkurniyawatirahim@gmail.com
}

\begin{abstract}
ABSTRAK
Penelitian yang berjudul "Analisis Minat Belajar Siswa Terhadap Mata Pelajaran Fisika Di SMA Negeri 1 Sakti" ini mengangkat masalah bagaimana minat belajar siswa di SMA Negeri 1 Sakti terhadap mata pelajaran fisika. Penelitian ini bertujuan untuk mengukur sejauh mana minat siswa SMA Negeri 1 Sakti terhadap mata pelajaran fisika. Subjek dalam penelitian ini adalah siswa jurusan IPA kelas kelas XI MIPA1 di SMA Negeri 1 Sakti, objek dalam penelitian ini adalah minat belajar siswa kelas XI MIPA1 di SMA Negeri 1 Sakti. Metode yang digunakan adalah metode penelitian studi kasus dengan pendekatan kualitatif. Pengumpulan data dilakukan dengan teknik pemberian angket pada siswa dan pengolahan data dilakukan dengan teknik Analysis Interactive model dari Miles dan Huberman. Selanjutnya membuat persentase dari hasil angket siswa. Berdasarkan hasil analisis data dari tiap indikator minat didapati bahwa secara keseluruhan siswa kelas XI MIPA1 di SMA Negeri 1 Sakti memiliki ketertarikan pada ilmu fisika dengan persentase rata-rata skor $48,4 \%$. Ketertarikan pada guru dengan persentase rata-rata skor $54,9 \%$. Ada tujuan yang ingin dicapai untuk kedepannya dengan persentase rata-rata skor $40,9 \%$. Keberhasilan dalam pembelajaran dengan persentase rata-rata skor $72,8 \%$. Menemukan manfaat dalam proses belajar dengan persentase rata-rata skor 70,6\%. Mempunyai inisiatif untuk belajar dengan persentase rata-rata skor $72,8 \%$. Konsentrasi dalam belajar dengan persentase rata-rata skor $77,3 \%$. Kemauan dalam belajar dengan persentase rata-rata skor 81,8\%. Berdasarkan hasil analisis tersebut menunjukkan bahwa siswa di SMA Negeri 1 Sakti memiliki minat yang baik terhadap mata pelajaran fisika. Disarankan penelitian yang berhubungan dengan analisis minat belajar siswa pada jenjang SMA/MA maupun pada jenjang SMP/Mts dapat dilanjutkan oleh peneliti lain sehingga dapat terungkap hal-hal yang belum terungkap dalam penelitian ini.
\end{abstract}

Kata Kunci : Analisis minat belajar siswa, angket, pelajaran fisika

\section{ABSTRACT}

The study, entitled "Analysis of Student Learning Interest in Physics Subjects in SMA Negeri 1 Sakti" raises the issue of how students' interest in learning at SMA Negeri 1 Sakti is towards physics. This study aims to measure the extent of the interest of students of SMA Negeri 1 Sakti towards physics. The subjects in this study were students majoring in Natural Sciences class XI MIPA1 in SMA Negeri 1 Sakti, the object of this study was the interest in learning for students of class XI MIPA1 in SMA Negeri 1 Sakti. The method used is a case study research method with a qualitative approach. Data collection was carried out using questionnaire delivery techniques for students and data processing was carried out using Analysis Interactive models from Miles and Huberman. After all, the result of data were presented in some precentages. Based on the results of data analysis of each indicator of interest it was found that overall XI MIPA1 students in SMA Negeri 1 Sakti had an interest in physics with an average percentage score of $48.4 \%$. Interest in 
teachers with an average percentage score of 54.9\%. There are goals to be achieved for the future with an average percentage of a score of $40.9 \%$. Success in learning with an average percentage score of $72.8 \%$. Finding benefits in the learning process with an average percentage of $70.6 \%$. Have the initiative to learn with an average percentage of $72.8 \%$. Concentration in learning with an average percentage score of $77.3 \%$. Willingness in learning with an average percentage score of $81.8 \%$. Based on the results of the analysis shows that students in SMA Negeri 1 Sakti have a good interest in physics. It is recommended that research related to the analysis of students' learning interest at the SMA / MA level and at the SMP / Mts level be continued by other researchers so that things that have not been revealed in this study can be revealed

Keywords: Analysis of student learning interst, questionnaire, physics

\section{Pendahuluan}

SMA Negeri 1 Sakti merupakan salah satu sekolah yang masuk dalam kategori sangat bagus dalam hal penerapan pola pendidikan. SMA Negeri 1 Sakti juga termasuk salah satu sekolah tingkat menengah atas yang tertua di kabupaten pidie yang sudah berdiri sejak tahun 1977 dan berakreditasi A. Di sekolah tersebut juga terdapat sejumlah siswa yang menempuh perjalanan yang cukup jauh untuk menuntut ilmu serta mempunyai tenaga pendidik yang cukup banyak, baik dari segi PNS maupun yang masih honorer. Akan tetapi untuk guru di bidang fisika masih cukup minim jika dibandingkan dengan jumlah siswa dan banyaknya kelas yang ada di sekolah tersebut sehingga mengakibatkan kurang maksimalnya proses pembelajaran yang berlangsung.

Berdasarkan observasi yang telah penulis lakukan didapati siswa yang ada di sekolah SMA Negeri 1 Sakti tidak dapat memfokuskan diri pada penyampaian yang dilakukan oleh gurunya dan seringkali siswa sulit untuk dapat mengerti apa yang di sampaikan oleh guru. Pelajaran fisika juga dianggap menjadi suatu pelajaran yang tidak menarik, sukar, membosankan dan juga menakutkan bagi siswa. Disinilah tugas seorang guru sebagai pendidik yang harus berusaha untuk mencari penyebab yang paling mendasar sehingga timbul anggapan yang seperti itu. Sebenarnya apa yang mareka alami dan mareka rasakan sehingga menyebabkan siswa menjadi beranggapan demikian terhadap mata pelajaran fisika.

Apakah karena rendahnya kesadaran diri terhadap pemenuhan rasa ingin tahu atau kebutuhan akan informasi dalam belajar sehingga menyebabakan siswa tersebut malas dalam mengikuti proses pembelajaran. Hal tersebut dapat memberikan dampak negatif bagi siswa sehingga siswa tersebut menjadi kurang berminat dalam belajar. Akibat dari kurangnya minat belajar siswa adalah siswa seringkali berbicara saat guru sedang menjelaskan materi sehingga pada saat pengambilan nilai, siswa pada umumnya mendapatkan nilai yang buruk. Disamping itu terkadang ada siswa yang membolos karena minat belajarnya yang sangat kurang. Jika siswa tidak berminat dan tidak berkemampuan dalam mata pelajaran fisika maka akan makin sedikit siswa yang menyukai mata pelajaran fisika. Berdasarkan latar belakang yang telah diuraikan masalah yang akan diteliti dalam penelitian ini adalah bagaimana minat belajar siswa SMA Negeri 1 Sakti terhadap mata pelajaran fisika? Berdasarkan rumusan masalah tujuan penelitian ini adalah untuk mengukur sejauh mana minat Siswa SMA Negeri 1 Sakti terhadap mata pelajaran fisika.

Minat merupakan salah satu aspek psikis yang dapat mendorong manusia mencapai tujuan. Seseorang yang memiliki minat terhadap suatu obyek, cenderung memberikan perhatian atau merasa senang yang lebih besar terhadap obyek tersebut. 
Apabila obyek tersebut tidak menimbulkan rasa senang, maka orang itu tidak akan memiliki minat terhadap obyek tersebut. Oleh karena itu tinggi rendahnya perhatian atau rasa senang seseorang terhadap obyek dipengaruhi oleh tinggi rendahnya minat orang tersebut. Menurut Djaali (2008) "minat pada dasarnya adalah penerimaan akan suatu hubungan diri sendiri dengan sesuatu diluar diri. Semakin kuat atau dekat hubungan tersebut maka akan semakin besar minatnya". Adanya hubungan seseorang dengan sesuatu diluar dirinya, dapat menimbulkan rasa ketertarikan, sehingga tercipta adanya penerimaan. Dekat maupun tidak hubungan tersebut akan mempengaruhi besar kecilnya minat yang ada. Menurut Hurlock (1989) "minat diartikan sebagai sumber motivasi yang akan mengarahkan seseorang terhadap apa yang akan mereka lakukan apabila diberi kebebasan untuk memilihnya bila mereka melihat sesuatu yang memiliki arti bagi dirinya". Menurut Hamdi (2015) "Proses pembelajaran dengan mudah diarahkan berpusat pada siswa untuk meningkatkan motivasi, minat, kreativitas, inisiatif, inspirasi, kemandirian, dan semangat belajar".

Dengan demikian minat adalah kesadaran seseorang terhadap sesuatu dan yang mendorong orang tersebut untuk memusatkan perhatian terhadap sesuatu itu dengan disertai perasaan puas dan senang. Titik awal untuk keberhasilan dalam mengajar adalah dengan membangkitkan minat belajar siswa karena rangsangan. Rangsangan tersebut membawa pada perasaan senang siswa terhadap pelajaran dan membangkitkan semangat untuk belajar. Jika minat siswa dibangkitkan maka seluruh perhatian dipusatkan pada mata pelajaran yang akan dipelajarinya. Minat merupakan salah satu faktor yang berpengaruh terhadap peningkatan pemahaman siswa dalam belajar. Dari beberapa definisi diatas, dapat ditarik kesimpulan bahwa minat adalah suatu perhatian yang dimiliki seseorang terhadap sesuatu dan disertai dengan keinginan untuk mengetahui dan mempelajari maupun membuktikan lebih lanjut dengan apa yang menjadi perhatiannya.

Ciri-ciri bahwa seseorang mempunyai minat menurut Hurlock (dalam Susanto, 2013: 62) yaitu: (1) Minat tumbuh bersamaan dengan perkembangan fisik dan mental. (2) Minat tergantung pada kegiatan belajar. (3) Minat tergantung pada kesempatan belajar. (4) Perkembangan minat mungkin terbatas yang mungkin dikarenakan keadaan fisik yang tidak memungkinkan. (5) Minat dipengaruhi budaya, jika budaya sudah mulai luntur mungkin minat juga ikut luntur. (6) Minat berbobot emosional. Minat berhubungan dengan perasaan, maksudnya bila suatu obyek dihayati sebagai sesuatu yang sangat berharga, maka akan timbul perasaan senang yang akhirnya dapat diminatinya. (7)Minat berbobot egosentris, artinya jika seseorang senang terhadap sesuatu, maka akan timbul hasrat untuk memilikinya. Untuk mengetahui apakah siswa berminat dalam belajar, dapat dilihat dari beberapa indikator mengenai minat belajar. Indikator ini disusun berdasarkan aspek minat siswa. Aspek minat siswa yang dimaksud adalah kesukaan, ketertarikan, perhatian, dan keterlibatan. Berdasarkan aspek tersebut, Rasyid (2010) merumuskan indikator tentang minat belajar siswa sebagai berikut : (1)Tertarik pada pelajaran, (2)Tertarik pada guru, (3)Keberhasilan dalam belajar, (4)Menemukan manfaat dalam proses belajar, (5)Mempunyai inisatif untuk belajar, (6)Konsentrasi dalam belajar, (7)Kemauan dalam belajar, (8)Ada tujuan yang ingin dicapai.

\section{Metode}

Pendekatan penelitian ini adalah pendekatan kualitatif, yang dimaksud dengan kualitatif adalah penelitian yang lebih menekankan pada aspek pemahaman secara 
mendalam terhadap suatu masalah dari pada melihat permasalahan untuk penelitian generalisasi. Jenis metode penelitian ini adalah penelitian studi kasus (case study). Studi kasus merupakan suatu penelitian yang dilakukan terhadap suatu kesatuan sistem. Kesatuan ini dapat berupa program, kegiatan, peristiwa, atau sekelompok individu yang terikat oleh tempat, waktu, atau ikatan tertentu. Studi kasus adalah suatu penelitian yang diarahkan untuk menghimpun data, mengambil makna, memperoleh pemahaman dari kasus tersebut. Kasus sama sekali tidak mewakili populasi dan tidak dimaksudkan untuk memperoleh kesimpulan dari populasi. Kesimpulan studi kasus hanya berlaku untuk kasus tersebut. Tiap kasus bersifat unik atau memiliki karakteristik sendiri yang berbeda dengan kasus lainnya. Suatu kasus dapat terdiri atas satu unit atau lebih dari satu unit, tetapi merupakan satu kesatuan. Kasus dapat disebabkan oleh satu orang, satu kelas, satu sekolah, beberapa sekolah tetapi dalam satu ruang lingkup. Dalam studi kasus digunakan beberapa teknik pengumpulan data seperti wawancara, observasi, dan studi dokumenter, tetapi semuanya difokuskan kearah mendapatkan kesatuan dan kesimpulan. Subjek pada penelitian ini adalah siswa jurusan IPA kelas XI MIPA 1 di SMA Negeri 1 Sakti sebanyak 22 orang. Yang menjadi objek dalam penelitian ini adalah minat belajar siswa kelas XI MIPA 1 di SMA Negeri 1 Sakti.

Teknik yang digunakan oleh penulis adalah angket atau kuesioner, yang kemudian diberikan kepada subjek penelitian. Kartono (2009:217) mengatakan, angket/quesioner merupakan:

"satu set pertanyaan yang berurusan dengan satu topik tunggal yang saling berkaitan, yang harus dijawab oleh subjek. Angket ini digunakan untuk penyelidikan mengenai suatu masalah yang banyak menyangkut kepentingan umum (orang banyak), dengan cara mengedarkan formulir daftar pentanyaan, diajukan secara tertulis kepada subjek untuk mendapatkan jawaban (tanggapan,respons) tertulis seperlunya".

Pada dasarnya angket tergolong dalam dua kategori, yaitu angket terbuka dan angket tertutup. Dalam penelitian ini penulis akan memberikan angket terbuka kepada para narasumber. Hal ini bertujuan agar narasumber nanti lebih leluasa untuk mengemukakan apa yang dia rasakan. Dalam pembuatan kuisioner minat memerlukan kisikisi kuisioner minat. Secara keseluruhan kuisioner ini memiliki total 15 butir pertanyaan. Kisi-kisi kuiesioner minat ditunjuk pada tabel berikut.

Tabel 1. Kisi-Kisi Kuesioner Minat Belajar Siswa

\begin{tabular}{|c|c|c|c|c|c|}
\hline $\begin{array}{c}\text { Asp } \\
\text { ek }\end{array}$ & $\begin{array}{l}\text { Infor } \\
\text { masi } \\
\text { Yang } \\
\text { Ingin } \\
\text { Dicar } \\
\quad \text { i } \\
\end{array}$ & $\begin{array}{l}\text { Indik } \\
\text { ator }\end{array}$ & $\begin{array}{c}\text { Contoh } \\
\text { Pertany } \\
\text { aan }\end{array}$ & $\begin{array}{c}\text { Juml } \\
\text { ah } \\
\text { Butir } \\
\text { Soal }\end{array}$ & $\begin{array}{l}\text { No } \\
\text { Item }\end{array}$ \\
\hline 1 & 2 & 3 & 4 & 5 & 6 \\
\hline & \multirow{3}{*}{$\begin{array}{c}\text { Kesuk } \\
\text { aan }\end{array}$} & $\begin{array}{l}\text { Keter } \\
\text { tarika } \\
\mathrm{n} \\
\text { pada } \\
\text { ilmu }\end{array}$ & $\begin{array}{l}\text { Apakah } \\
\text { dengan } \\
\text { mempela } \\
\text { jari fisika } \\
\text { kita lebih } \\
\text { dekat } \\
\text { dengan } \\
\text { alam? }\end{array}$ & 3 & $1,2,3$ \\
\hline & & $\begin{array}{l}\text { Keter } \\
\text { tarika } \\
\mathrm{n} \\
\text { pada } \\
\text { guru }\end{array}$ & $\begin{array}{l}\text { Apakah } \\
\text { guru } \\
\text { fisika } \\
\text { yang saat } \\
\text { ini } \\
\text { mengajar } \\
\text { dikelas } \\
\text { anda } \\
\text { menyena } \\
\text { ngkan? }\end{array}$ & 2 & 4,5 \\
\hline & & $\begin{array}{l}\text { Ada } \\
\text { tujua } \\
n \\
\text { yang } \\
\text { ingin } \\
\text { dicap }\end{array}$ & $\begin{array}{l}\text { Apakah } \\
\text { anda } \\
\text { ingin } \\
\text { melanjut } \\
\text { kan } \\
\text { kuliah }\end{array}$ & 1 & 15 \\
\hline
\end{tabular}




\begin{tabular}{|c|c|c|c|c|}
\hline & ai & $\begin{array}{l}\text { dibidang } \\
\text { fisika? }\end{array}$ & & \\
\hline \multirow[t]{2}{*}{$\begin{array}{c}\text { Kepua } \\
\text { san }\end{array}$} & $\begin{array}{l}\text { Keber } \\
\text { hasila } \\
\mathrm{n} \\
\text { dalam } \\
\text { pemb } \\
\text { elajar } \\
\text { an }\end{array}$ & $\begin{array}{l}\text { Apakah } \\
\text { anda } \\
\text { yakin } \\
\text { hal-hal } \\
\text { yang } \\
\text { dipelajari } \\
\text { dalam } \\
\text { pelajaran } \\
\text { fisika } \\
\text { akan } \\
\text { memberi } \\
\text { kan } \\
\text { banyak } \\
\text { manfaat } \\
\text { bagi anda } \\
\text { ? }\end{array}$ & 2 & 6,7 \\
\hline & $\begin{array}{l}\text { Mene } \\
\text { muka } \\
\mathrm{n} \\
\text { manf } \\
\text { aat } \\
\text { dalam } \\
\text { prose } \\
\mathrm{s} \\
\text { belaja } \\
\text { r }\end{array}$ & $\begin{array}{l}\text { Apakah } \\
\text { setelah } \\
\text { mengikut } \\
\text { i } \\
\text { pelajaran } \\
\text { ini, anda } \\
\text { jadi tahu } \\
\text { hubunga } \\
\text { n antar } \\
\text { ilmu } \\
\text { yang } \\
\text { anda } \\
\text { pelajari } \\
\text { dengan } \\
\text { hal-hal } \\
\text { yang ada } \\
\text { dalam } \\
\text { kehidupa } \\
\text { n sehari- } \\
\text { hari ? }\end{array}$ & 2 & 8,9 \\
\hline $\begin{array}{l}\text { Keterl } \\
\text { ibatan }\end{array}$ & $\begin{array}{l}\text { Mem } \\
\text { punya } \\
\mathrm{i} \\
\text { inisiat } \\
\text { if } \\
\text { untuk } \\
\text { belaja } \\
\mathrm{r}\end{array}$ & $\begin{array}{l}\text { Pernahka } \\
\mathrm{h} \text { anda } \\
\text { mengula } \\
\text { ng } \\
\text { kembali } \\
\text { pelajaran } \\
\text { fisika } \\
\text { yang } \\
\text { telah } \\
\text { anda } \\
\text { pelajari } \\
\text { disekolah } \\
\text { setelah } \\
\text { sampai } \\
\text { dirumah } \\
\text { ? }\end{array}$ & 2 & 10,11 \\
\hline & Kons & Apakah & 2 & 12,13 \\
\hline
\end{tabular}

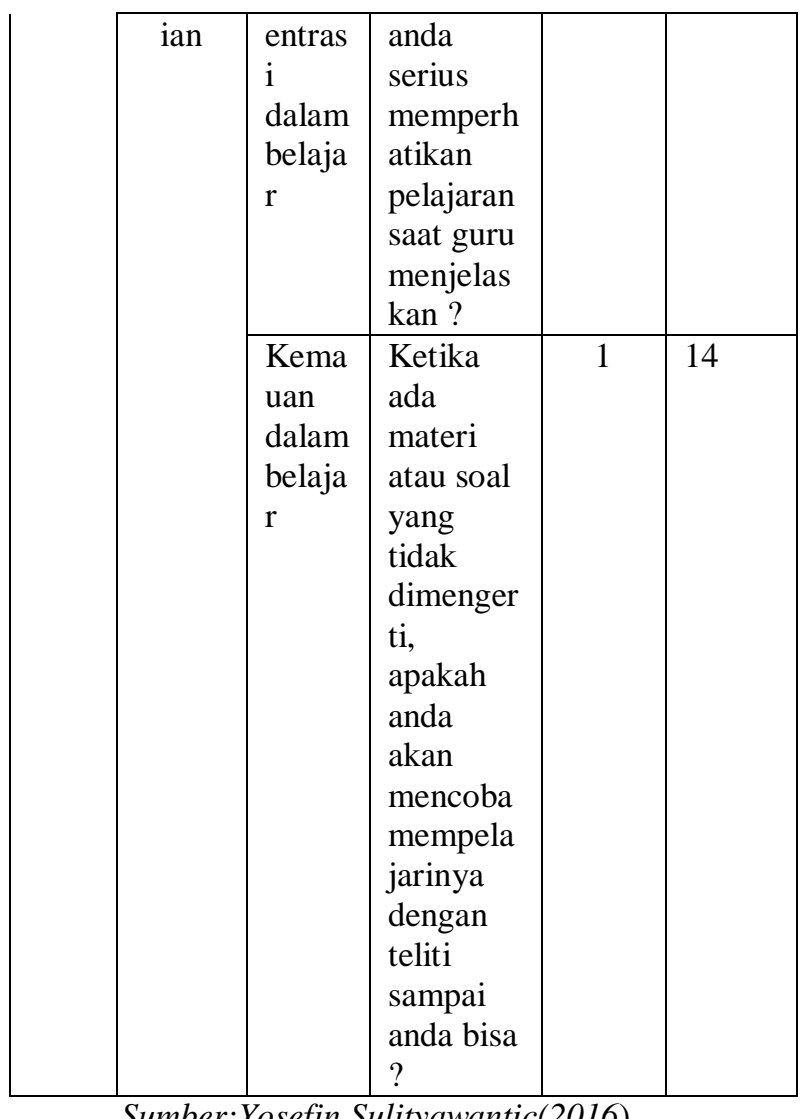

Sumber:Yosefin Sulityawantic(2016)

Data dari jawaban kuesioner yang telah dijawab oleh responden nantinya akan dibuat dalam bentuk persentase dengan menggunakan rumus :

$$
P=\frac{f}{n} x 100 \% \text {..............Sugiyono }
$$

(2013)

$\mathrm{P}=$ Persentase $(\%)$

$f=$ Frekuensi dari tiap jawaban angket

$n=$ Jumlah responden

Analisis data dalam penelitian ini menggunakan teknik analisis data dalam situs yang dikembangkan oleh Miles dan Huberman. Data yang sudah terkumpul dibuat dalam bentuk matriks. Dalam matriks tersebut akan disajikan penggalan-penggalan data deskriptif sekitar peristiwa atau pengalaman tertentu yang menyekat data sebelum dan sesudahnya. Setelah data dimasukkan kedalam matriks selanjutnya 
dibuat daftar cek (Miles Huberman, 2007: 139-140).

Untuk menyajikan data agar mudah dipahami, maka langkah-langkah analisis data yang digunakan dalam penelitian ini adalah Analisys Interactivemodel dari Miles dan Huberman, yang membagi langkahlangkah dalam kegiatan analisis data dengan beberapa bagian yaitu pengumpulan data (data colection), reduksi data (data redection), penyajian data (data display) dan penarikankesimpulan atau verifikasi (conclutions).

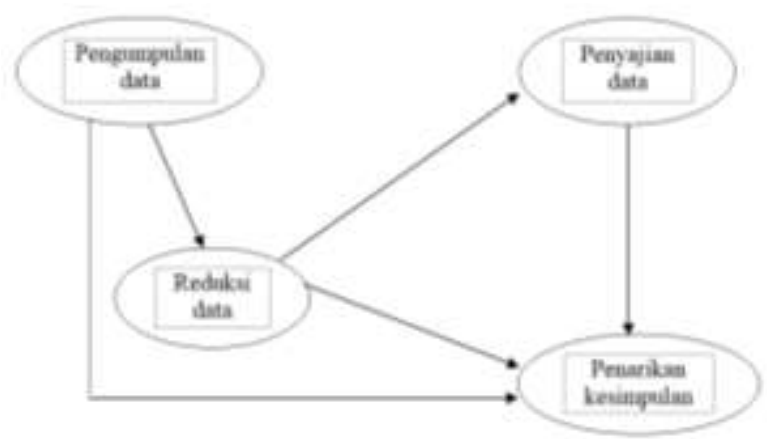

Gambar 1. Langkah-Langkah Analisis Data Milles Huberman (2007

\section{1) Pengumpulan Data}

Pada analisis model pertama dilakukan pengumpulan data hasil observasi dan pembagian angket yang sesuai dengan masalah penelitian yang kemudian dikembangkan penajaman data melalui pencarian data selanjutnya.

2) Reduksi Data

Miles dan Huberman (2007:16) mengatakan bahwa "reduksi data adalah suatu bentuk analisis yang menajamkan, menggolongan, mengarahkan, membuang data yang tidak perludan mengorganisasi data dengan cara sedemikian rupa sehingga simpulan final dapat ditarik dan diverifikasi".

3) Penyajian Data

Miles dan Huberman(2007: 84) mengatakan bahwa "sajian data adalah suatu rangkaian organisasi informasi yang memungkinkan kesimpulan riset dapat dilakukan. Penyajiandata dimaksudkan untuk menemukan pola-polayang bermakna serta memberikan kemungkinan adanya penarikan simpulan serta memberikan tindakan".

Menurut Harsono(2008: 169)"sajian data berupa narasi kalimat, gambar atau skema, jaringan kerja dan tabel sebagai narasinya". Pada tahap ini peneliti akan membuat penyajian data berdasarkan jawaban dari angket dalam dua kategori yaitu, jawaban positif menunjukkan siswa memiliki minat terhadap pelajaran fisika dan jawaban negatif menunjukkan bahwa siswa tidak memiliki minat terhadap pelajaran fisika.

Tabel 2. Skor Jawaban Angket

\begin{tabular}{|c|l|c|}
\hline No & \multicolumn{1}{|c|}{$\begin{array}{c}\text { Kategori } \\
\text { Jawaban }\end{array}$} & Skor \\
\hline 1 & Positif & 5 \\
\hline 2 & Negatif & 4 \\
\hline
\end{tabular}

4) Penarikan Kesimpulan

Menurut Harsono

(2008:169)

"Penarikan kesimpulan merupakan bagian dari suatu kegiatan konfigurasi yang utuh. Kesimpulan-kesimpulan juga diverifikasi selama penelitian berlangsung. Kesimpulan ditarik semenjak peneliti menyusun pencatatan, pola- pola, pernyataanpernyataan, konfigurasi, arahan sebab akibat, dan berbagai proposisi".

\section{Hasil dan Pembahasan Hasil}

Data yang telah dikumpulkan dianalisis dengan tujuan dapat menarik kesimpulan dengan baik. Pengolahan data yang masuk ditempuh dengan cara menstabulasi dan menafsirkan tiap-tiap data dari masingmasing responden kemudian dibuat dalam bentuk persentase. Adapun hasil persentase sejumlah pertanyaan yang penulis berikan 
kepada para responden dapat dilihat pada tabel-tabel di bawah ini:

Tabel 3. Siswa Senang Mempelajari Fisika

\begin{tabular}{|l|c|c|}
\hline \multicolumn{1}{|c|}{$\begin{array}{c}\text { Alternatif } \\
\text { Jawaban }\end{array}$} & F & \% \\
\hline Positif & 14 & 63,6 \\
\hline Negatif & 8 & 36,4 \\
\hline Total & 22 & 100 \\
\hline
\end{tabular}

Tabel 4. Dengan Mempelajari Fisika Siswa Lebih Dekat Dengan Alam

\begin{tabular}{|l|l|c|}
\hline Alternatif Jawaban & F & \% \\
\hline Positif & 10 & 45,5 \\
\hline Negatif & 12 & 54,5 \\
\hline Total & $\mathbf{2 2}$ & $\mathbf{1 0 0}$ \\
\hline
\end{tabular}

Tabel 5. Fisika Mudah Menimbulkan Kebosanan

\begin{tabular}{|l|l|c|}
\hline \multicolumn{1}{|c|}{$\begin{array}{c}\text { Alternatif } \\
\text { Jawaban }\end{array}$} & F & \% \\
\hline Positif & 9 & 40,9 \\
\hline Negatif & 13 & 59,1 \\
\hline Total & $\mathbf{2 2}$ & $\mathbf{1 0 0}$ \\
\hline
\end{tabular}

Tabel 6. Guru Fisika Yang Saat Ini Mengajar Menyenangkan

\begin{tabular}{|l|c|c|}
\hline \multicolumn{1}{|c|}{$\begin{array}{c}\text { Alternatif } \\
\text { Jawaban }\end{array}$} & F & \% \\
\hline Positif & 15 & 68,2 \\
\hline Negatif & 7 & 31,8 \\
\hline Total & $\mathbf{2 2}$ & $\mathbf{1 0 0}$ \\
\hline
\end{tabular}

Tabel 7. Siswa Akan Tetap Belajar Siapapun Guru Yang Mengajar Dikelas

\begin{tabular}{|l|c|c|}
\hline \multicolumn{1}{|c|}{$\begin{array}{c}\text { Alternatif } \\
\text { Jawaban }\end{array}$} & F & \% \\
\hline Positif & 9 & 40,9 \\
\hline Negatif & 13 & 59,1 \\
\hline Total & $\mathbf{2 2}$ & $\mathbf{1 0 0}$ \\
\hline
\end{tabular}

Tabel 8. Fisika Memberikan Banyak Manfaat Bagi Siswa

\begin{tabular}{|l|c|c|}
\hline \multicolumn{1}{|c|}{$\begin{array}{c}\text { Alternatif } \\
\text { Jawaban }\end{array}$} & F & \% \\
\hline Positif & 15 & 40,9 \\
\hline Negatif & 7 & 59,1 \\
\hline Total & $\mathbf{2 2}$ & $\mathbf{1 0 0}$ \\
\hline
\end{tabular}

Tabel 9. Keyakinan Akan Berhasil Dalam Pelajaran Fisika

\begin{tabular}{|l|c|c|}
\hline \multicolumn{1}{|c|}{$\begin{array}{c}\text { Alternatif } \\
\text { Jawaban }\end{array}$} & F & \% \\
\hline Positif & 17 & 77,3 \\
\hline Negatif & 5 & 22,7 \\
\hline Total & $\mathbf{2 2}$ & $\mathbf{1 0 0}$ \\
\hline
\end{tabular}

Tabel 10. Siswa Jadi Tahu Hubungan Antara Ilmu Fisika Dengan Kehidupan Sehari-Hari

\begin{tabular}{|l|c|c|}
\hline $\begin{array}{c}\text { Alternatif } \\
\text { Jawaban }\end{array}$ & F & \% \\
\hline Positif & 16 & 72,7 \\
\hline Negatif & 6 & 27,3 \\
\hline Total & $\mathbf{2 2}$ & $\mathbf{1 0 0}$ \\
\hline
\end{tabular}

Tabel 11. Selain Memberikan Pengetahuan Fisika Juga Memberikan Banyak Pengalaman Berharga

\begin{tabular}{|l|c|c|}
\hline $\begin{array}{c}\text { Alternatif } \\
\text { Jawaban }\end{array}$ & F & \% \\
\hline Positif & 15 & 68,2 \\
\hline Negatif & 7 & 31,8 \\
\hline Total & $\mathbf{2 2}$ & $\mathbf{1 0 0}$ \\
\hline
\end{tabular}

Tabel 12. Siswa Mengulang Kembali Apa Yang Telah Diajarkan

Disekolah Setelah Sampai Dirumah

\begin{tabular}{|l|c|c|}
\hline \multicolumn{1}{|c|}{$\begin{array}{c}\text { Alternatif } \\
\text { Jawaban }\end{array}$} & F & \% \\
\hline Positif & 15 & 68,2 \\
\hline Negatif & 7 & 31,8 \\
\hline Total & $\mathbf{2 2}$ & $\mathbf{1 0 0}$ \\
\hline
\end{tabular}


Tabel 13. Siswa Mempersiapkan Pelajaran Untuk Esok Hari

\begin{tabular}{|l|c|c|}
\hline \multicolumn{1}{|c|}{$\begin{array}{c}\text { Alternatif } \\
\text { Jawaban }\end{array}$} & F & \% \\
\hline Positif & 17 & 77,3 \\
\hline Negatif & 5 & 22,7 \\
\hline Total & $\mathbf{2 2}$ & $\mathbf{1 0 0}$ \\
\hline
\end{tabular}

Tabel 14. Siswa Serius Memperhatikan Saat Guru Menjelaskan

\begin{tabular}{|l|c|c|}
\hline \multicolumn{1}{|c|}{$\begin{array}{c}\text { Alternatif } \\
\text { Jawaban }\end{array}$} & F & \% \\
\hline Positif & 17 & 77,3 \\
\hline Negatif & 5 & 22,7 \\
\hline Total & $\mathbf{2 2}$ & $\mathbf{1 0 0}$ \\
\hline
\end{tabular}

Tabel 15. Siswa Merasa Terganggu Jika Ada Teman Mengajak Bicara Disaat Belajar

\begin{tabular}{|l|c|c|}
\hline \multicolumn{1}{|c|}{$\begin{array}{c}\text { Alternatif } \\
\text { Jawaban }\end{array}$} & F & \% \\
\hline Positif & 17 & 77,3 \\
\hline Negatif & 5 & 22,7 \\
\hline Total & $\mathbf{2 2}$ & $\mathbf{1 0 0}$ \\
\hline
\end{tabular}

Tabel 16. Siswa Akan Berusaha Sampai Bisa Jika Ada Materi Atau Soal Yang Tidak Dimengerti

\begin{tabular}{|l|c|c|}
\hline \multicolumn{1}{|c|}{$\begin{array}{c}\text { Alternatif } \\
\text { Jawaban }\end{array}$} & F & \% \\
\hline Positif & 18 & 81,8 \\
\hline Negatif & 4 & 18,2 \\
\hline Total & $\mathbf{2 2}$ & $\mathbf{1 0 0}$ \\
\hline
\end{tabular}

Tabel 17. Siswa Ingin Kuliah Dibidang Fisika

\begin{tabular}{|l|c|c|}
\hline $\begin{array}{c}\text { Alternatif } \\
\text { Jawaban }\end{array}$ & F & \% \\
\hline Positif & 9 & 40,9 \\
\hline Negatif & 13 & 59,1 \\
\hline Total & $\mathbf{2 2}$ & $\mathbf{1 0 0}$ \\
\hline
\end{tabular}

\section{Pembahasan}

Berdasarkan data di atas dapat diketahui bahwa tingkat minat belajar siswa terhadap mata pelajaran fisika di SMA Negeri 1 Sakti masih perlu mendapatkan perhatian lagi baik dari guru (pendidik) dan lingkungan sekitarnya. Tingkat minat belajar siswa terhadap mata pelajaran fisika di SMA Negeri 1 Sakti dapat dilihat dari analisis data penulis berupa angket. Berdasarkan data dari angket di atas minat belajar siswa terhadap mata pelajaran fisika masih perlu diperhatikan lagi di SMA Negeri 1 Sakti. Dimana hal ini terlihat dari indikator minat siswa dalam ketertarikan pada ilmu, ketertarikan pada guru dan ada tujuan yang ingin dicapai siswa terhadap mata pelajaran fisika harus lebih ditingkatkan lagi agar siswa lebih berminat dalam belajar fisika.

Faktor-faktor yang mempengaruhi minat belajar siswa terhadap mata pelajaran fisika di SMA Negeri 1 Sakti, yaitu kurangnya motivasi, kurangnya rasa senang terhadap mata pelajaran fisika. Dan siswapun tidak mempunyai keinginan dari dalam diri untuk belajar fisika, contohnya siswa akan belajar fisika tergantung pada siapa guru yang akan mengajar.

Selain faktor-faktor di atas ada pula aktor-faktor yang mempengaruhi minat belajar siswa di SMA Negeri 1 Sakti, yaitu dorongan dari dalam diri siswa, guru, orang tua dan teman untuk menunjang kelancaran dalam kegiatan belajar mengajar. Dorongan guru, orang tua dan teman tersebut apabila cukup terpenuhi akan menimbulkan adanya minat yang dimiliki oleh para siswa. Dorongan dari dalam diri siswa sangat berpengaruh besar terhadap minat belajar siswa, dorongan dari dalam diri siswa ini berupa keinginan belajar dari pribadi siswa tersebut.

Dorongan seorang pendidik yang dapat menimbulkan minat siswa adalah dengan memberikan strategi dan metode yang menarik didalam kegiatan belajar mengajar 
dan harus selalu memberikan motivasi dan semangat pada setiap siswanya, khususnya dalam mata pelajaran fisika. Karena mata pelajaran fisika merupakan salah satu mata pelajaran yang diujikan dalam ujian nasional, maka pendidik harus memberikan keyakinan bahwa dengan mempelajari fisika dengan serius siswa dapat mengerjakan ujian dengan mudah nantinya.

Dorongan dari orang tua juga sangat diperlukan bagi siswa untuk menimbulkan minat belajar siswa. Agar minat belajar terhadap anaknya bisa mulai timbul, maka sebagai orang tua harus memberikan perhatian kepada setiap anaknya tentang belajar di sekolah dan melihat tingkat nilai yang dimiliki oleh anaknya berdasarkan tingkat kemampuannya. Orang tua juga jangan terlalu memarahi anaknya jika mendapatkan nilai yang tidak memuaskan, tetapi sebagai orang tua harus memberikan motivasi dan semangat pada anaknya masing-masing.

Selain dorongan dari dalam diri, pendidik dan orang tua yang dapat menimbulkan minat belajar siswa, tapi ada juga dorongan dari seorang teman yang dapat menimbulkan minat belajar. Seorang teman juga memiliki peran seperti orang tua dan pendidik yang memberikan motivasi dan semangat positif kepada temannya untuk meraih dan mencapai sesuatu yang diinginkan oleh temannya sendiri.

Seberapa besar pengaruh faktor-faktor yang mempengaruhi minat belajar siswa terhadap mata pelajaran fisika, yaitu dengan mempelajari fisika siswa jadi lebih dekat dengan alam hanya $45,6 \%$ dan $54,5 \%$ siswa itu mengatakan mereka tidak menjadi lebih dekat dengan alam setelah belajar fisika. Hal itu dapat dilihat dari tabel 4.8. Siswa di SMA Negeri 1 Sakti tidak memiliki tujuan mendalam untuk kedepannya dalam belajar fisika, hal ini bisa dilihat dari persentase pada tabel 4.21. Sebanyak 40,9\% siswa ingin menempuh perkuliahan di bidang fisika, sedangkan sebanyak 59,1\% siswa sama sekali tidak ingin menempuh perkuliahan di bidang fisika.

Siswa SMA Negeri 1 Sakti kurang memiliki minat terhadap mata pelajaran fisika, contohnya seperti tabel 4.9 dimana hanya sebanyak $40,9 \%$ siswa yang tidak bosan dalam belajar fisika sedangkan sebanyak 59,1\% siswa bosan dalam mengikuti mata pelajaran fisika. Tabel 4.11 siswa hanya akan belajar fisika tergantung pada siapa guru yang akan mengajar, hal ini dapat dilihat dari persentasenya. Sebanyak 40,9\% siswa akan belajar siapapun guru yang mengajar, sedangkan 59,1\% siswa hanya akan belajar fisika tergantung dengan guru yang mengajar. Berdasarkan hal tersebut peran guru dalam memberikan motivasi sangat diperlukan.

Dorongan dari orang tua siswa dalam meningkatkan minat belajar siswa di SMA Negeri 1 Sakti sudah cukup memuaskan. Hal ini terlihat dari hasil persentase pada tabel 4.16 dan 4.17. Sebanyak 68,2\% siswa mengulang kembali apa yang telah dipelajari di sekolah setelah tiba di rumah, sedangkan sisanya sebanyak $31,8 \%$ siswa tidak pernah mengulang kembali apa yang telah dipelajari setelah tiba di rumah. Dan juga sebanyak $77,3 \%$ siswa selalu belajar dimalam hari dan mempersiapkan pelajaran untuk esok hari, sedangkan $22,7 \%$ siswa tidak melakukannya.

Dorongan dari dalam diri siswa juga sudah sangat memuaskan, hal ini bisa dilihat dari persentase pada tabel 4.13, tabel 4.18 dan tabel 4.20. Dimana sebanyak 77,3\% siswa memiliki keyakinan akan berhasil dalam pelajaran fisika, sedangkan sisanya sebanyak 22,7\% merasa tidak yakin akan berhasil dalam pelajaran fisika. Dan juga sebanyak 77,3\% siswa serius mendengarkan saat guru menjelaskan, sedangkan sebanyak $22,7 \%$ siswa tidak memperhatikan saat guru menjelaskan pelajaran. Serta sebanyak $81,8 \%$ siswa akan berusaha sampai bisa jika ada materi atau soal yang tidak dimengerti, 
sedangkan sisanya sebanyak $18,8 \%$ siswa tidak berusaha sampai bisa jika ada materi atau soal yang tidak dimengerti.

Dorongan dari guru di SMA Negeri 1 Sakti sudah cukup maksimal, hal ini bisa dilihat dari hasil persentase pada tabel 4.7, tabel 4.10, tabel 4.11, tabel 4.14 dan tabel 4.15. sebanyak $63,6 \%$ siswa merasa senang mempelajari fisika, sedangkan sebanyak $36,4 \%$ siswa merasa tidak senang mempelajari fisika. Sebanyak $68,2 \%$ siswa mengatakan bahwa guru fisika yang mengajar saat ini menyenangkan, sedangkan sebanyak $31,8 \%$ siswa mengatakan bahwa guru yang mengajar saat ini tidak menyenangkan. Sebanyak $68,2 \%$ siswa mengatakan fisika memberikan banyak manfaat, sedangkan sebanyak 31,8\% siswa mengatakan bahwa fisika sama sekali tidak memberika manfaat meskipun mereka telah belajar fisika sebelumnya. Sebanyak 72,7\% siswa jadi tahu hubungan ilmu fisika dengan kehidupan sehari-hari, sedangkan 27,3\% siswa sama sekali tidak tahu hubungan antara fisika dengan kehidupan sehari-hari meskipun mereka telah belajar. Dan sebanyak 68,2\% siswa mengatakan bahwa fisika bukan hanya memberikan banyak pengetahuan tapi juga banyak pengalaman berharga, sedangkan sebanyak $31,8 \%$ siswa mengatakan bahwa fisika bukan hanya tidak memberikan pengetahuan dan juga tidak memberikan pengalaman berharga lainnya.

Dorongan dari teman dalam membantu meningkatkan minat belajar siswa terhadap mata pelajaran fisika di SMA Negeri 1 Sakti juga sudah cukup memuaskan, hal ini bisa dilihat dari hasil persentase pada tabel 4.19. Sebanyak $77,3 \%$ siswa sangat merasa terganggu jika ada teman yang mengajak berbicara saat belajar, sedangkan sebanyak $22,7 \%$ siswa mengatakan bahwa mereka tidak merasa terganggu jika ada teman yang mengajak berbicara saat belajar. Hal ini menunjukkan bahwa motivasi dari teman sudah diterapkan.

\section{Simpulan dan Saran Kesimpulan}

Penelitian tentang analisis minat belajar siswa terhadap mata pelajaran fisika di SMA Negeri 1 Sakti bertujuan untuk mengukur sejauh mana minat siswa SMA Negeri 1 Sakti terhadap mata pelajaran fisika. Berdasarkan hasil penelitian dan analisis data yang diperolah dari kuesioner, dapat ditarik kesimpulan bahwa siswa kelas XI MIPA ${ }_{1}$ di SMA Negeri 1 Sakti memiliki minat yang baik untuk mempelajari fisika dengan persentase secara keseluruhan adalah 64,9\%.

Sementara itu untuk hasil analisis terhadap tiap indikator minat didapatkan bahwa secara keseluruhan siswa kelas XI MIPA $_{1}$ di SMA Negeri 1 Sakti memiliki:

1. Ketertarikan pada ilmu fisika tergolong dalam kategori hampir baik dengan persentase rata-rata skor $48,4 \%$.

2. Ketertarikan pada guru tergolong dalam kategori baik dengan persentase rata-rata skor $54,9 \%$.

3. Ada tujuan yang ingin dicapai tergolong dalam kategori hampir baik dengan persentase rata-rata skor $40,9 \%$.

4. Keberhasilan dalam pembelajaran tergolong dalam kategori baik dengan persentase rata-rata skor $72,8 \%$.

5. Menemukan manfaat dalam proses belajar tergolong dalam kategori baik dengan persentase rata-rata skor $70,6 \%$.

6. Mempunyai inisiatif untuk belajar tergolong dalam kategori baik dengan persentase rata-rata skor $72,8 \%$.

7. Konsentrasi dalam belajar tergolong dalam kategori baik dengan persentase rata-rata skor $77,3 \%$.

8. Kemauan dalam belajar tergolong dalam kategori baik dengan persentase rata-rata skor $81,8 \%$.

Akan tetapi meskipun mereka memiliki minat yang baik untuk mempelajari fisika itu tidak menjadikan siswa tersebut memiliki keinginan untuk bekerja atau menjalani karir 
dalam bidang fisika. Hal ini bisa dilihat dari hasil persentase pada tabel 17 .

\section{Saran}

Berdasarkan kesimpulan diatas, maka penulis menyampaikan beberapa saran yaitu:

1. Hendaknya kepala sekolah SMA Negeri 1 Sakti bekerja sama dengan para guru agar mengadakan program untuk menimbulkan minat belajar siswa khususnya mata pelajaran fisika. Karena mata pelajaran fisika merupakan salah satu mata pelajaran yang diujikan dalam Ujian Nasional (UN).

2. Hendaknya guru-guru khususnya guru mata pelajara fisika memperhatikan faktor-faktor minat belajar siswa, faktorfaktor minat belajar siswa tersebut masih perlu ditingkatkan lagi. Karena faktorfaktor minat belajar siswa sangat dibutukan oleh siswa itu sendiri agar siswa tersebut dapat mencapai segala sesuatu yang diinginkannya.

3. Hendaknya setiap guru harus mengetahui seberapa besar pengaruh faktor-faktor minat belajar siswa tersebut untuk meningkatkan minat belajar siswa. Dengan mengetahui itu semua, maka akan menjadi tolak ukur bagi semua guru untuk selalu meningkatkan minat yang ada pada diri siswa masing-masing.

4. Untuk penelitian selanjutnya dapat ditambahkan dengan melakukan wawancara kepada beberapa siswa.

\section{Ucapan Terimakasih}

Pada kesempatan ini, penulis ingin menyampaikan rasa hormat dan ucapan terimakasih sedalam-dalamnya kepada semua pihak yang telah membantu penulisan skripsi ini, kepada:

1. Bapak Drs.Hamdi, M.Pd, selaku pembimbing utama yang juga telah mengarahkan penulis dengan penuh perhatian dan kesabarandalam menyelesaikan skripsi ini.
2. Bapak Muhammad Saiful, M.Pd, selaku pembimbing dua yang telah memberikan banyak waktu dan kesempatan untuk membimbing penulis dalam menyelesaikan skripsi ini.

3. Seluruh dosen prodi fisika yang telah memberikan bimbingan dan ilmu pengetahuan kepada penulis selama menempuh pendidikan pada program studi ini.

4. Drs. Sumarjo, SH., M.Pd, selaku dekan Fakultas Keguruan Dan Ilmu Pendidikan (FKIP)Universitas Jabal Ghafur yang telahmemberikan izin penelitian.

5. Ka. Tu dan staf administrasi Fakultas Keguruan Dan Ilmu Pendidikan (FKIP)Universitas Jabal Ghafur yang telah mendorong dan memberikan keperluan dalam penyusunan skripsi ini.

6. Kepala Sekolah SMA Negeri I Sakti beserta stafnya yang telah mengizinkan penulis mengadakan penelitian untukpenulisan skripsi ini.

7. Semua sahabat fisika dan semua pihak yang tidak dapat penulis sebutkan satu persatu yang telah membantu penulisan skripsi ini.

8. Ikhsan Maulana Saifuddin, atas segala bantuan, bimbingan, perhatian dengan penuh cinta dan keihklasanan dalam membantu penulis menyelesaikan penulisan skripsi ini.

9. Ayahanda dan Ibunda, atas segala pengorbanan, jerih payah, cinta dan kasih sayangnya dalam membesarkan dan mendidik serta do'anya sehingga penulis dapat belajar untuk memperdalam ilmu pengetahuan di Perguruan Tinggi.

\section{Daftar Pustaka}

Arikunto, Suharsimi. 2010. Prosedur Penelitian Suatu Pendekatan Praktik. Jakarta: Rineka Cipta.

Budiarti, Yeti. 2011. Minat Belajar Siswa. UIN Syarif Hidayatullah Jakarta.

Dalyono, M. 1997. Psikologi Pendidikan. Jakarta: Rineka Cipta. 
Depdikbud. 1991. Kamus Besar Bahasa Indonesia. Jakarta: Balai Pustaka.

Djaali. 2008. Psikologi Pendidikan. Jakarta: Bumi Aksara.

Hamdi. 2015. Pengembangan Dan Penerapan Modul Pembelajaran Materi Teori Dasar Dan Bentuk Muka Bumi Untuk Meningkatkan Kognitif Mahasiswa Pendidikan MIPA FKIP UNIGHA Sigli. Banda Aceh: Universitas Syiah Kuala.

Harsono. 2007. Pembiayaan Pendidikan. Yogyakarta: Surayajaya Press.

Harsono. 2008. Pengelolaan Perguruan Tinggi. Yogyakarta: Pustaka Pelajar.

Hurlock, Elisabeth B. 1989. Perkembangan Anak, Jilid 2. Jakarta: Erlangga.

Imran, Ali. 1996. Belajar dan Pembelajaran. Jakarta: PT Dunia Pustaka Jaya.

Kartono, Kartini. 2009. Pengantar Metodelogi Riset Sosial. Bandung : Mandar Maju.

Miles, Mattew B dan A. Michael Huberman. 2007. Analisis Data Kualitatif, Buku sumber tentang metode-metode baru. Jakarta: Universitas Indonesia Press.

Moeliono, M Anton. 1993. Tata Bahasa Baku Bahasa Indonesia. Jakarta: Balai Pustaka.

Moleong, Lexy J. 2010. Metodologi Penelitian Kualitatif. Bandung: Remaja Rosda.

Rasyid, 2010. Minat, Indikator Indikator Minat. Jakarta: Bumi Aksara.
Ruswandi, S.Pd. 2013. Psikologi Pembelajaran. Bandung: CV. Cipta Pesona Sejahtera.

Singer, Kurt. 1987. Membina Hasrta Belajar di Rumah (Terj. Bregman Sitorus). Bandung: Remaja Rosdakarya.

Slameto. 1995. Proses Belajar Mengajar. Universitas Muhammadiyah Surakarta.

Slameto. 2010. Belajar dan Faktor-Faktor Yang Mempengaruhinya. Jakarta: Rineka Cipta.

Sugiyono. 2009. Metode Penelitian Kuantitatif, Kualitatif, dan $R \& D$. Bandung: ALFABETA.

Sugiyono. 2013. Metode Penelitian Pendidikan Pendekatan Kuantitatif, Kualitatif, dan $R \& D$. Bandung: Alfabeta.

Sulistyawantic, Yoesefin. 2016. Minat Belajar Siswa SMA kelas XI-IPA terhadap mata pelajaran fisika di Kabupaten Nias Barat. Universitas Sanata Dharma Yogyakarta.

Susanto, Ahmad. 2013. Teori Belajar dan Pembinaan di Sekolah Dasar. Jakata: Kencana Prenadamedia Group.

Tampubolon, D,P. 1993. Mengembangkan Minat dan Kebiasaan Membaca Pada Anak. Bandung: Angkasa.

Winkel, W.S. 1996. Psikologi Pengajaran. Jakarta: Grasindo. 